Imágenes en Urología

\title{
Incarceración de pene por anillo metálico
}

David García Belmonte, José M ${ }^{\mathrm{a}}$ Gili Masso, Xavier Pascual García, Pascual González Uréndez, $\mathrm{M}^{\mathrm{a}}$ José Abadías Medrano, Jesús Guajardo Guajardo

Servicio de Urología. Hospital Arnau de Vilanova. Lleida. España.

$\mathrm{P}$ resentamos un caso clínico de una incarceración de pene, tras la colocación de un anillo grueso en zona balano-prepucial de pene y su posterior tratamiento.

Paciente varón de 56 años de edad que acude al Servicio de Urgencias de nuestro Hospital tras la colocación de anillo grueso para prolongar la erección de unas tres horas de evolución, acompañado por dolor y una retención aguda de orina.

A la exploración presenta globo vesical, testes en bolsas y en zona balano-prepucial de pene un color violáceo- oscuro piel, no se puede explorar glande por anillo fimótico del mismo y dolor a la palpación

Se decide la colocación de anestesia troncular pene y tras mejoría del dolor, se realiza compresión del pene pudiendo extraer el anillo, sin la necesidad de utilización de material ortopédico y sin cirugía.

Tras la retirada del anillo, el pene recupero el color normal, sin edema del prepucio y pudiendo comprobar el buen color del surco balano-prepucial. Tras descompresión del pene, el paciente presenta micciones espontáneas. Pudiendo ser dado de alta, $\mathrm{y}$ en control posterior en consultas, el paciente refiere tener buenas erecciones.

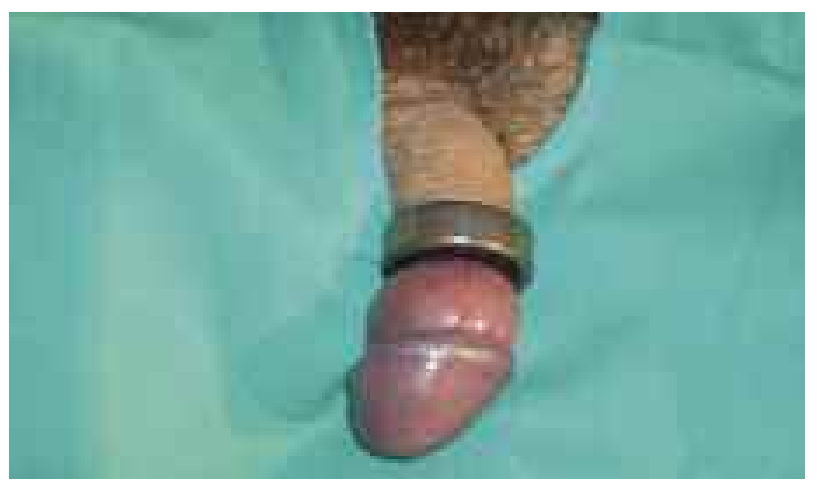

FIGURA 1

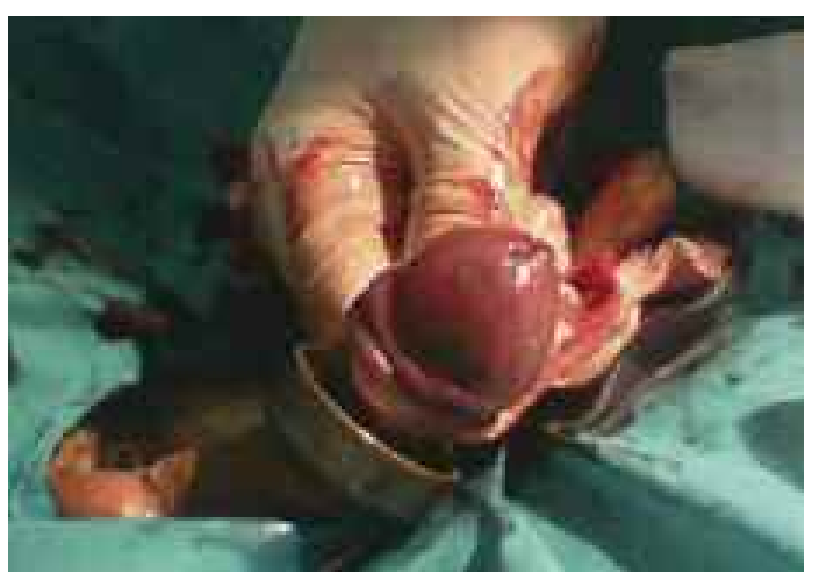

FIGURA 2

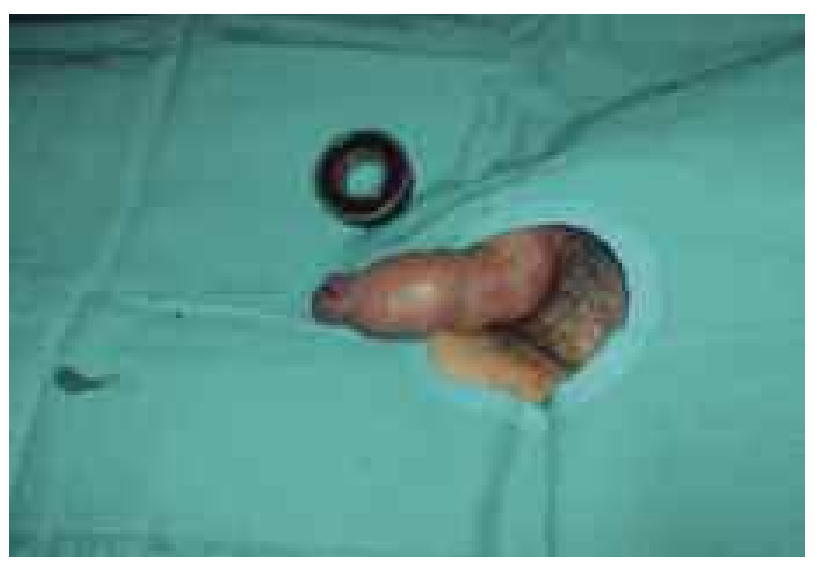

FIGURA 3

Correspondencia autor: Dr. David García Belmonte Servicio de Urología

Hospital Arnau de Vilanova

Avda. Alcalde Rovira Roure, 80 - 25198 Lleida

Tel.: 973248100

E-mail autor: drgarciabelmonte@hotmail.com

Información artículo: Imágenes en Urología

Trabajo recibido: noviembre 2007

Trabajo aceptado: diciembre 2007 